\title{
Nitrification of low concentration ammonia nitrogen using zeolite biological aerated filter (ZBAF)
}

\author{
Jin-Su Kim, Ji-Young Lee, Seung-Kyu Choi, Qian Zhu, Sang-Ill Lee ${ }^{\dagger}$ \\ Department of Environmental Engineering, Chungbuk National University, Cheongju, Republic of Korea
}

\begin{abstract}
This study focuses on nitrification through a biological aerated filter (BAF) that is filled with a zeolite medium at low concentrations of ammonia. The zeolite medium consists of natural zeolite powder. The BAF is operated under two types of media, which are a ball-type zeolite medium and expanded poly propylene (EPP) medium. Nitrification occurred in the zeolite BAF (ZBAF) when the influent concentration of ammonia nitrogen was $3 \mathrm{mg} \mathrm{L}-1$, but the BAF that was filled with an EPP medium did not experience nitrification. The ammonia nitrogen removal efficiency of ZBAF was $63.38 \%$ and the average nitrate nitrogen concentration was $1.746 \mathrm{mg} / \mathrm{L}$. The ZBAF was tested again after a comparison experiment to treat pond water, and municipal wastewater mixed pond water. The ZBAF showed remarkable ammonia-nitrogen treatment at low concentration and low temperature. During this period, the average ammonia nitrogen removal efficiency was $64.56 \%$. Especially, when water temperature decreased to $4.7^{\circ} \mathrm{C}$, ammonia nitrogen removal efficiency remained $79 \%$. On the other hand, the chemical-oxygen demand (COD) and phosphorus-removal trends were different. The COD and phosphorus did not show as efficient treatment as the ammonia-nitrogen treatment.
\end{abstract}

Keywords: Biological aerated filter, Low concentration, Low temperature, Nitrification, Zeolite

\section{Introduction}

Under low-concentration conditions, biological treatment experiences problems with maintaining high concentrations of biomass. This problem can decrease the removal efficiency during continuous treatment. In particular, nitrifying bacteria, such as nitrosomonas and nitrobacter are more difficult to maintain because they are autotrophic bacteria. During bio-filtration, sufficient biofilm formation requires a long contact time under low concentrations of influents. The concentration of ammonia nitrogen in wastewater-treatment plants is low, such as $3 \mathrm{mg} / \mathrm{L}$, but this amount can still cause problems in water-treatment plants and the environment. Low concentrations of ammonia nitrogen in natural aqueous environments can consume dissolved oxygen (DO), become toxic to organisms, and cause eutrophication. Such low concentrations of ammonia nitrogen are generally removed through cation exchange resin or zeolite adsorption [1,2].

Zeolite has been widely used and studied for ammonia-nitrogen adsorption, showing high adsorption ability [3-6]. Zeolite has remarkably selective cation-exchange ability with ammonium [3]. The ammonium-ion exchange of zeolite media can be represented by the following reaction (1) [4]:

$$
\left(\text { Zeolite- } \mathrm{Na}^{+} \text {or } \mathrm{K}^{+}\right)+\mathrm{NH}_{4}^{+} \rightarrow\left(\text { Zeolite- } \mathrm{NH}_{4}^{+}\right)+\mathrm{Na}^{+} \text {or } \mathrm{K}^{+}(1)
$$

In particular, low concentrations of ammonium can be removed easily by using zeolite [1, 2]. However, regeneration is necessary to use zeolite continuously over long periods $[1,7,8]$. Regeneration methods include chemical regeneration and biological regeneration. The chemical-regeneration method is generally used with sodium chloride $(\mathrm{NaCl})$, but this method experiences problem with regeneration during water treatment and regeneration of sodium chloride cause a problem for drinking water treatment [7]. The biological-regeneration method is mainly used in connection with chemical regeneration [8]. Ordinary regeneration methods are temporally or spatially separated during adsorption.

During the treatment of low concentrations of ammonium, the zeolite and attached growth nitrifying biofilms can supplemented each other [9]. When ammonia-oxidation bacteria (AOB) attaches to zeolite media, the latter can be continually regenerated from the attached AOB, while the AOB can utilize adsorbed ammonium on the zeolite. Zeolite can concentrate ammonium from wastewater
This is an Open Access article distributed under the terms of the Creative Commons Attribution Non-Commercial License (http://creativecommons.org/licenses/by-nc/3.0/) which permits unrestricted non-commercial use, distribution, and reproduction in any medium, provided the original work is properly cited.

Copyright (C) 2020 Korean Society of Environmental Engineers
Received March 20, 2019 Accepted August 07, 2019

${ }^{\dagger}$ Corresponding author

Email: gatorlee@chungbuk.ac.kr

Tel: +82-43-261-2469 Fax: +82-43-272-2469

ORCID: 0000-0003-2009-5978 
onto the zeolite medium's surface. Under low concentrations of ammonia nitrogen, zeolite media can assist the growth and maintenance of $\mathrm{AOB}$ populations.

In this study, a biological aerated filter (BAF) that is filled with zeolite media is used to treat wastewater with low concentrations of ammonium. Previous studies on BAFs improved the efficiency of organic-matter removal and nitrification [10-19]. When zeolite media was used in BAFs, nitrification occurred at high-influent conditions and showed high efficiency. Qiu et al. [12] were compared nitrification properties of BAF filled with natural zeolite, ceramic and carbonate media, and zeolite media was shown more suitable nitrification performance. Ji et al. [13] operated multi-media biological aerated filter (MBAF) containing clinoptilolite and brick-type bioceramsite and confirmed the change of ammonia nitrogen removal efficiency by hydraulic loading and influent ammonia nitrogen loading. Chang et al. [14] and Chang et al. [16] showed that zeolite biological aerated filters (ZBAF) have higher nitrification efficiency when treating textile wastewater. He et al. [14] and Feng et al. [17] reported that ZBAFs have more resistance than BAFs at lower water temperatures. Li et al. [18] reported that modified zeolite more beneficial to the specific immobilization of AOB than natural zeolite, nitrite nitrogen accumulating was observed. Yang et al. [19] enhanced the partial-nitrification efficiency through using
ZBAFs. However, these previous studies were performed under normal or high influent concentrations. Therefore, low concentration ammonium wastewater was influent into BAF filled with zeolite medium to confirm the nitrification efficiency.

\section{Materials and Methods}

\subsection{Characteristic of Media}

The comparison experiments were performed with ball-type zeolite and cylindrical-type EPP media. Each medium photo and scanning electron microscope (SEM) photo are shown in Fig. 1. The diameter of the ball-type zeolite media was $3 \sim 5 \mathrm{~mm}$, and the EPP media was $5 \mathrm{~mm}$ in diameter and $5 \mathrm{~mm}$ in length. The chemical composition of the zeolite media is given in Table 1. The ball-type zeolite media consisted of natural zeolite powder and was ignited at $900^{\circ} \mathrm{C}$.

Each medium was packed with an identical volume of $1.6 \mathrm{~L}$. The weights of the packed zeolite and EPP media were $1.2 \mathrm{~kg}$ and $0.4 \mathrm{~kg}$, respectively. Prior to operation, each medium was aerated for $8 \mathrm{~h}$ with an activated sludge for microbe attachment. Activated sludge was used from return sludge from the municipal wastewater-treatment plant in Cheongju, Korea.

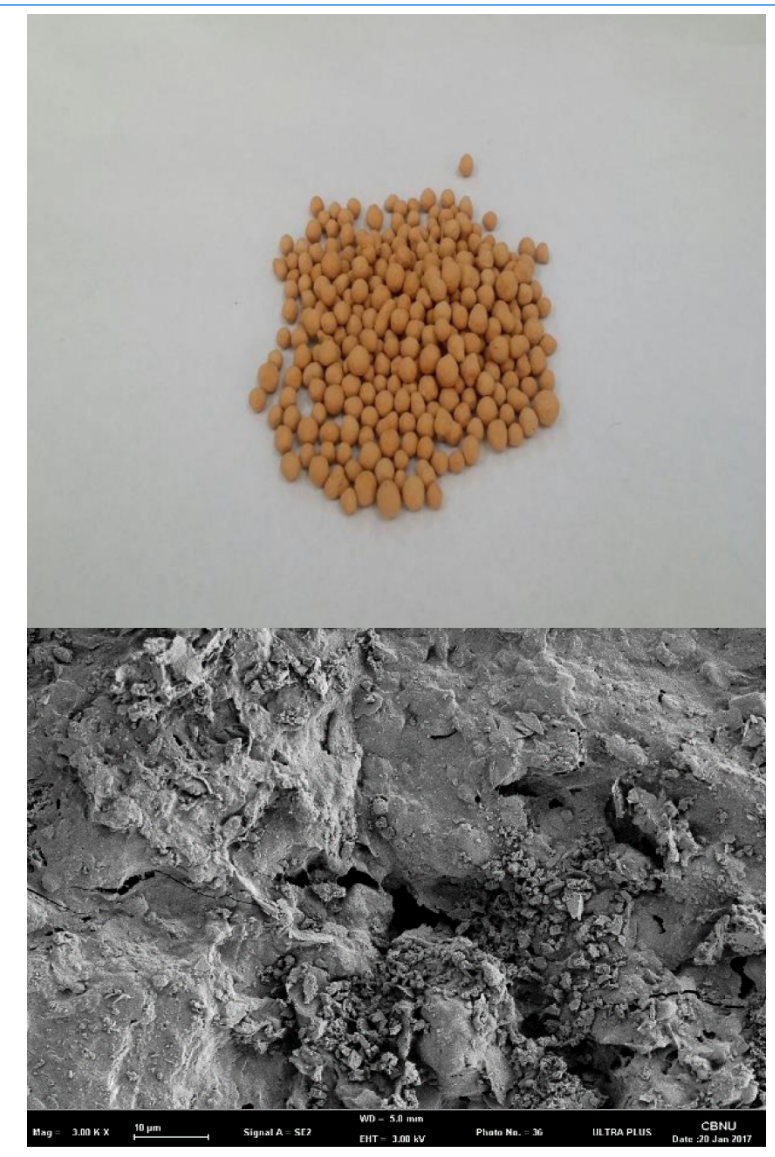

Zeolite media

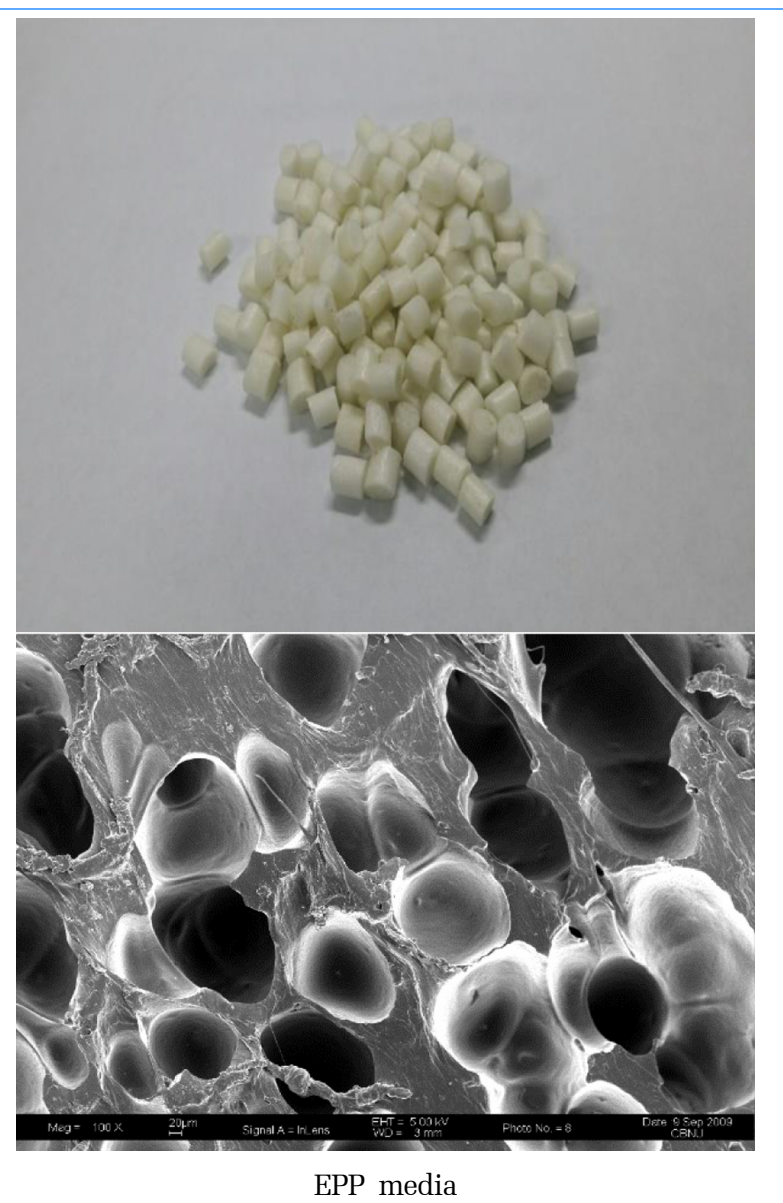

Fig. 1. Zeolite and EPP media photo and SEM photo. SEM photo magnification of Zeolite media is 3,000 and EPP media is 100 . 
Table 1. Chemical Composition of Zeolite Media (\%)

\begin{tabular}{ccccccc}
\hline $\mathrm{SiO}_{2}$ & $\mathrm{Al}_{2} \mathbf{O}_{3}$ & $\mathrm{Fe}_{3} \mathbf{O}_{3}$ & $\mathbf{C a O}$ & $\mathbf{M g O}$ & $\mathbf{K 2 O}$ & $\mathbf{N a O}$ \\
\hline 67.1 & 17.6 & 2.93 & 3.29 & 1.78 & 3.06 & 3.02 \\
\hline
\end{tabular}

\subsection{Experimental Setup}

The BAF's volume was $1.6 \mathrm{~L}$, and this filter used the downflow-filtration method (Fig. 2). This filter was a cylinder with a funnel bottom (total height of $30 \mathrm{~cm}$, diameter of $9.5 \mathrm{~cm}$, and funnel-bottom height of $12.5 \mathrm{~cm}$ ). Aeration was supplied through a pipe at the bottom of the BAF, and treated wastewater flowed out with air through an inner pipe in the BAF. In the middle of the inner pipe, some of the air flowed through a hole to produce aeration. Influent air flow was $0.5 \mathrm{~L} \mathrm{~min}^{-1}$.

Experiment was conducted in two steps. First, the zeolite media was compared to an EPP media, which had no ammonium-adsorption ability. Second, pond water with low ammonia-nitrogen concentration was treated through a ZBAF, and the removal efficiencies of ammonia nitrogen and another material were determined. To confirm phosphorus removal, the ZBAF was operated through mixed wastewater, which contained municipal wastewater, as influent.

The treatment time was determined from the empty-bed contact time (EBCT), and the EBCTs of the comparison experiment and pond-water treatment were 25 and $60 \mathrm{~min}$, respectively. The influent wastewater used synthetic wastewater and pond water. The comparison experiment was conducted by using synthetic wastewater. Synthetic wastewater was prepared from tap water with an ammonia-nitrogen concentration of $3 \mathrm{mg} \mathrm{L}^{-1}$ by using ammonia sulfate

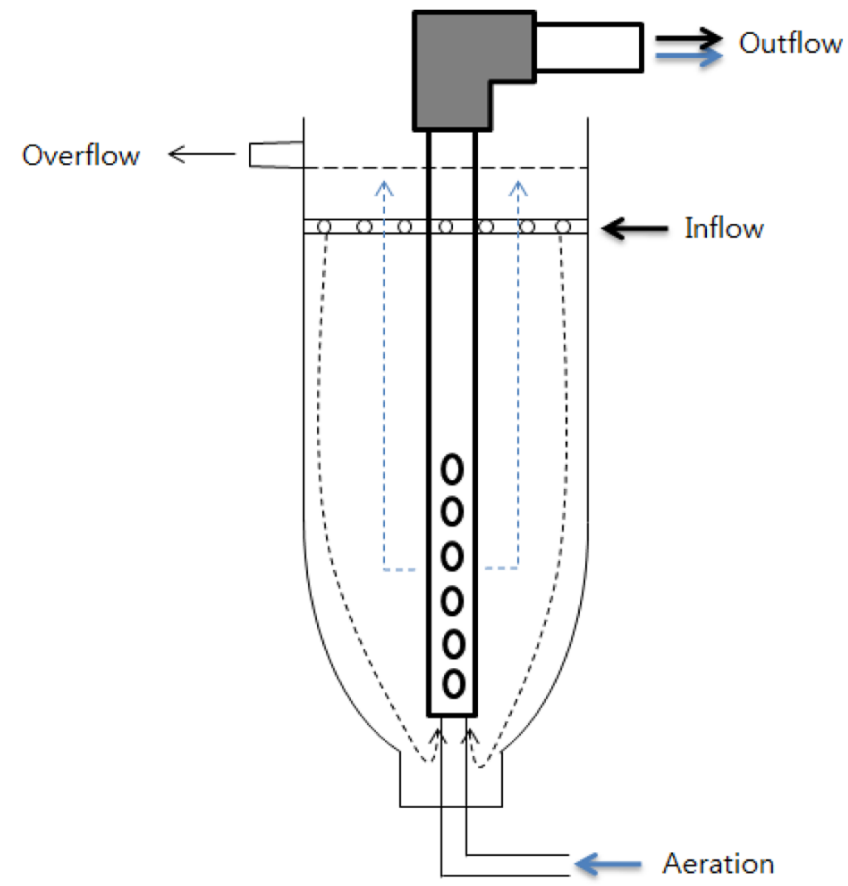

Fig. 2. Schematic diagram of ZBAF for this study. The black dotted line represents the flow of air and the blue dotted line is wastewater flow.
Table 2. Characteristics of Pond Water and Pond Water Mixed Municipal Wastewater

\begin{tabular}{lcc}
\hline Parameter & Pond water & $\begin{array}{c}\text { Pond water mixed with } \\
\text { municipal wastewater }\end{array}$ \\
\hline $\mathrm{NH}_{4}{ }^{+}-\mathrm{N}, \mathrm{mg} \mathrm{L}^{-1}$ & $0.365 \pm 0.388$ & $3.543 \pm 2.086$ \\
$\mathrm{TCOD}_{\mathrm{Cr}}, \mathrm{mg} \mathrm{L}^{-1}$ & $29.923 \pm 10.323$ & $6.973 \pm 6.035$ \\
$\mathrm{SCOD}_{\mathrm{Cr}}, \mathrm{mg} \mathrm{L}^{-1}$ & $17.483 \pm 4.940$ & $4.982 \pm 3.399$ \\
$\mathrm{TP}, \mathrm{mg} \mathrm{L}^{-1}$ & $0.190 \pm 0.220$ & $0.869 \pm 0.742$ \\
$\mathrm{OP}, \mathrm{mg} \mathrm{L}^{-1}$ & $0.022 \pm 0.052$ & $0.203 \pm 0.132$ \\
$\mathrm{SS}, \mathrm{mg} \mathrm{L}$ & $38.475 \pm 25.175$ & $34.845 \pm 73.180$ \\
$\mathrm{VSS}, \mathrm{mg} \mathrm{L}^{-1}$ & $27.950 \pm 13.091$ & $20.597 \pm 55.043$ \\
\hline
\end{tabular}

$\left(\left(\mathrm{NH}_{4}\right)_{2} \mathrm{SO}_{4}\right)$. Pond water was collected from Chungbuk National University in Cheongju, Korea. To increase the ammonia-nitrogen concentration, $10 \%(\mathrm{~V} / \mathrm{V})$ of the municipal wastewater from the Cheongju municipal wastewater-treatment plant was mixed with the pond water. The concentration of wastewater is presented in Table 2. When only pond water was influent, the average concentration of $\mathrm{NH}_{4}{ }^{+}-\mathrm{N}$, total chemical-oxygen demand $\left(\mathrm{TCOD}_{\mathrm{Cr}}\right)$, soluble chemical-oxygen demand ( $\mathrm{SCOD}_{\mathrm{Cr}}$ ), total phosphorus (TP), orthophosphate (OP), suspended solids (SS), and volatile suspended solids (VSS) were $0.365 \pm 0.388 \mathrm{mg} \mathrm{L}^{-1}, 29.923 \pm 10.323 \mathrm{mg} \mathrm{L}^{-1}, 17.483 \pm 4.940$ $\mathrm{mg} \mathrm{L}^{-1}, 0.190 \pm 0.220 \mathrm{mg} \mathrm{L}^{-1}, 0.022 \pm 0.052 \mathrm{mg} \mathrm{L}^{-1}, 38.475 \pm 25.175$ $\mathrm{mg} \mathrm{L}^{-1}$, and $27.950 \pm 13.091 \mathrm{mg} \mathrm{L}^{-1}$, respectively. When the pond water that was mixed with municipal wastewater was influent, the average concentrations of $\mathrm{NH}_{4}{ }^{+}-\mathrm{N}, \mathrm{TCOD}_{\mathrm{Cr}}, \mathrm{SCOD}_{\mathrm{Cr}}$, TP, OP, SS, and VSS were $3.543 \pm 2.086 \mathrm{mg} \mathrm{L}^{-1}, 6.973 \pm 6.035 \mathrm{mg} \mathrm{L}^{-1}, 4.982$ $\pm 3.399 \mathrm{mg} \mathrm{L}^{-1}, 0.869 \pm 0.742 \mathrm{mg} \mathrm{L}^{-1}, 0.203 \pm 0.132 \mathrm{mg} \mathrm{L}^{-1}, 34.845$ $\pm 73.180 \mathrm{mg} \mathrm{L}^{-1}$, and $20.597 \pm 55.043 \mathrm{mg} \mathrm{L}^{-1}$, respectively.

\subsection{Analytical Procedures}

Chemical analyses were performed according to the procedures in the Standard Methods and HACH manuals. The samples were analyzed for $\mathrm{TCOD}_{\mathrm{Cr}}$ and $\mathrm{SCOD}_{\mathrm{Cr}}$ (closed reflux, colorimetric method 5220 D), OP (ascorbic acid method 4500-P E), $\mathrm{NO}_{2}^{-}-\mathrm{N}$ (colorimetric method $4500-\mathrm{NO}_{2}{ }^{-} \mathrm{B}$ ), and $\mathrm{NO}_{3}{ }^{-}-\mathrm{N}$ (ultraviolet spectrophotometric screening method $4500-\mathrm{NO}_{3}^{-}$B) from the Standard Methods. $\mathrm{NH}_{4}-\mathrm{N}$ (Nessler method) and T-P (PhosVer3 with the acid persulfate-digestion method) were determined from the $\mathrm{HACH}$ manuals. The water temperature and $\mathrm{pH}$ were measured by using a pH meter (Orion 4 Star pH·ISE Benchtop, Thermo Scientific).

\section{Results and Discussion}

\subsection{Low-Concentration Ammonia-nitrogen Removal}

The ammonia-nitrogen-removal efficiency of the ZBAF and BAF is shown in Fig. 3. Each reactor was operated with an EBCT of 
$25 \mathrm{~min}$ and the average influent ammonia-nitrogen concentration was $2.978 \pm 0.316 \mathrm{mg} \mathrm{L}^{-1}$. Under these conditions, the average ammonia-nitrogen-removal efficiency of the ZBAF and BAF was $63.38 \pm 4.08 \%$ and $3.79 \pm 3.13 \%$, respectively. The ammonia-nitrogen-removal efficiency of the ZBAF was maintained even when the influent concentration was below $3 \mathrm{mg} \mathrm{L}^{-1}$. The nitrate nitrogen concentration of effluent was also confirmed only in the ZBAF, and the average concentration was $1.746 \pm 0.335 \mathrm{mg} \mathrm{L}^{-1}$. Nitrification did not occur in the BAF that was filled with an EPP medium, even though activated sludge was added twice.

The zeolite medium showed significant differences in nitrification efficiency compared to the EPP medium. This performance showed that nitrification could only be maintained in the zeolite medium at low concentrations of ammonia-nitrogen influent. In particular, the zeolite did not need an adaptation period for nitrification, and nitrification reactions could be directly observed. The zeolite could concentrate ammonia nitrogen from water onto the zeolite medium's surface because zeolite has cation-exchange ability [3, 4]. This performance could assist and maintain AOB growth at low influent concentrations. At the same time, zeolite media are regenerated by nitrifiers as ammonia nitrogen is converted into nitrite and nitrate nitrogen. The nitrite or nitrate nitrogen is desorbed from the zeolite and sodium is located again. This reaction can be represented by Eq. (2) and (3):

$$
\begin{gathered}
\text { Ion exchange: }\left(\text { Zeolite-Na }{ }^{+}\right)+\mathrm{NH}_{4}^{+} \rightarrow \\
\left(\text { Zeolite- } \mathrm{NH}_{4}^{+}\right)+\mathrm{Na}^{+}
\end{gathered}
$$

Regeneration (nitrification): (Zeolite- $\left.\mathrm{NH}_{4}{ }^{+}\right) \rightarrow$ $\left(\right.$ Zeolite-Na $\left.{ }^{+}\right)+\mathrm{NO}_{2}^{-} \rightarrow\left(\right.$ Zeolite- $\left.\mathrm{Na}^{+}\right)+\mathrm{NO}_{3}$

In previous studies, zeolite enhanced nitrification efficiency when applied to high-concentration wastewater [14, 15]. However, in this experiment, the zeolite media showed superior ability at low concentrations and more greatly affected nitrification efficiency. Thus, zeolite media can selectively grow and maintain AOB.

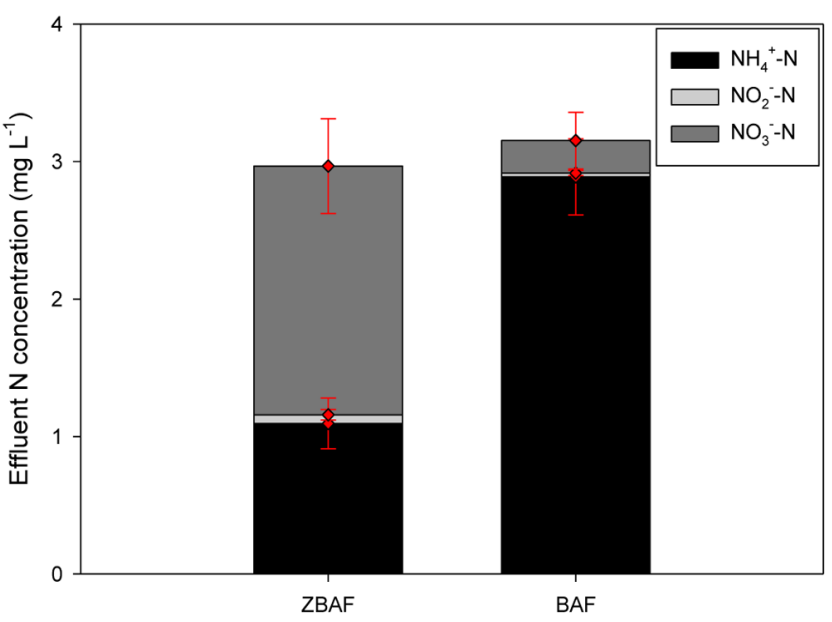

Fig. 3. Sum of nitrogen type comparison $\mathrm{ZBAF}$ and $\mathrm{BAF}$ during operation time.

\subsection{Pond-water Ammonia-nitrogen Removal for the ZBAF and the Water-temperature Effect}

In this experiment, the ZBAF was operated with an EBCT of 60 min. The influent pond-water ammonia-nitrogen concentration was 0.025 - $1.576 \mathrm{mg} \mathrm{L}^{-1}$, almost always remaining below $0.5 \mathrm{mg} \mathrm{L}^{-1}$ (Fig. 4(a)). When municipal wastewater was mixed with pond water, the ammonia-nitrogen concentration was higher. The average removal efficiency during the entire operation time was $64.56 \%$; however, the average removal efficiency of only pond-water influent was $56.44 \%$, showing a higher standard deviation than the mixed-wastewater influent. The removal efficiency was irregular at low concentrations, such as influent concentrations under 0.5 $\mathrm{mg} \mathrm{L}^{-1}$; however, the amount of ammonia nitrogen that was removed remained constant compared to the influent ammonia-nitrogen concentration (Fig. 4(b)). The removed ammonia-nitrogen trend was linear. Regardless of the low and high concentrations, the treatment trend was almost constant. Zeolite media can adsorb ammonia nitrogen consistently and continuously through the regeneration of attached AOB $[8,16]$.
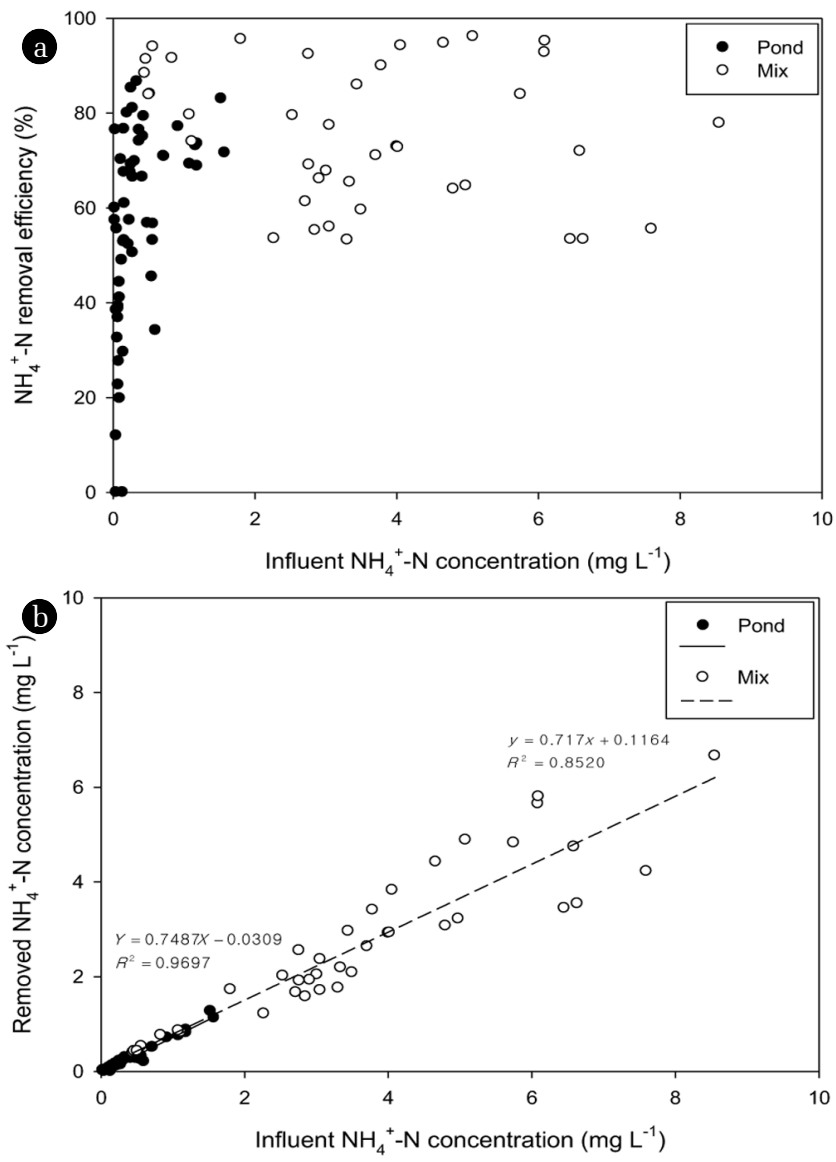

Fig. 4. (a) Ammonia nitrogen removal efficiency according to influent concentration, and (b) Removed ammonia nitrogen concentration according to influent concentration. When the pond water was influent, water temperature range was 4.7 to $20^{\circ} \mathrm{C}$. When the mixed wastewater was influent, water temperature range was 5.6 to $16.1^{\circ} \mathrm{C}$. 
The ammonia-nitrogen removal's correlation to the water temperature was not significant (Fig. 4(b)). The removal efficiency was slightly higher even at lower temperatures. Generally, nitrification is critically affected by water-temperature changes. Many researchers used and studied biofilm technology, such as moving bed biofilm reactors (MBBR) or BAFs, to solve nitrification problems at low temperature $[15,20,21]$. When the water temperature decreases, the ammonia-nitrogen-removal efficiency greatly decreases and only gradually recovers after a long period of adaptation to low temperatures [15]. However, in this study, the ZBAF was not affected by low water temperature; this performance coincides with that from another study [15]. Nitrification occurred even when the water temperature was below $10^{\circ} \mathrm{C}$. When the water temperature suddenly decreased to $4.7^{\circ} \mathrm{C}$, the ammonia-nitrogen-removal efficiency remained $79 \%$. The ZBAF maintained high nitrification efficiency even under low water temperatures and sudden temperature decreases. Thus, ZBAFs are applicable in Northern
Hemispheric countries with cold or seasonal climates, such as Korea. ZBAFs can be an alternative to solve this problem because of its stable treatment efficiency regardless of temperature changes.

\subsection{Organic Matter and Phosphorous-Removal Efficiency}

Differently from the ammonia-nitrogen treatment, the COD and phosphorus-removal efficiency were low during the entire operation period with the ZBAF. The average removal efficiency of TCOD, SCOD, TP, and OP was 12.64\%, 5.18\%, 4.98\%, and $1.38 \%$, respectively.

The influent COD concentration was also low, and the average concentrations of influent TCOD and SCOD were $29.92 \mathrm{mg} \mathrm{L}^{-1}$ and $17.45 \mathrm{mg} \mathrm{L}^{-1}$, respectively. Unlike the ammonia-nitrogen treatment, the influent and effluent COD concentrations were similar; the COD barely changed during the operation period (Fig. 5). Generally, pond water contains natural organic matter (NOM), which is known to be a non-degradable organic substance [22].
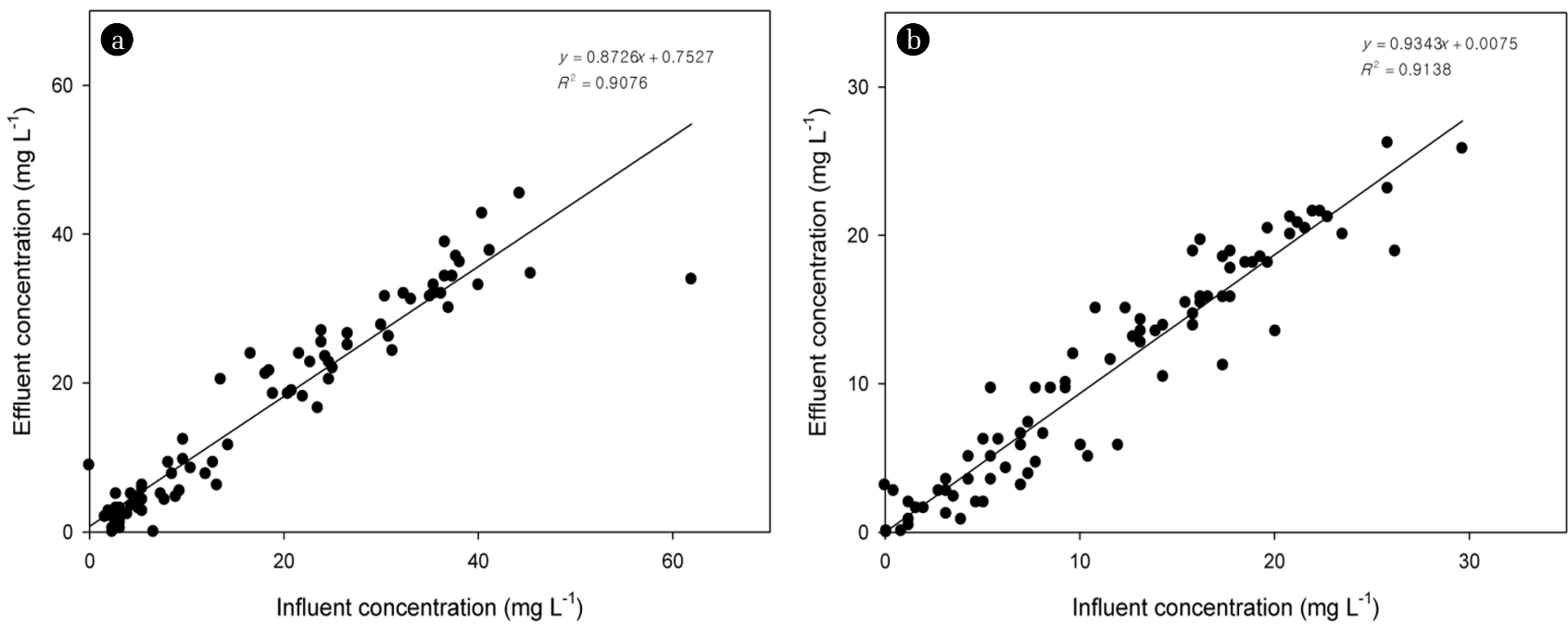

Fig. 5. Concentration of effluent COD according to influent COD concentration.
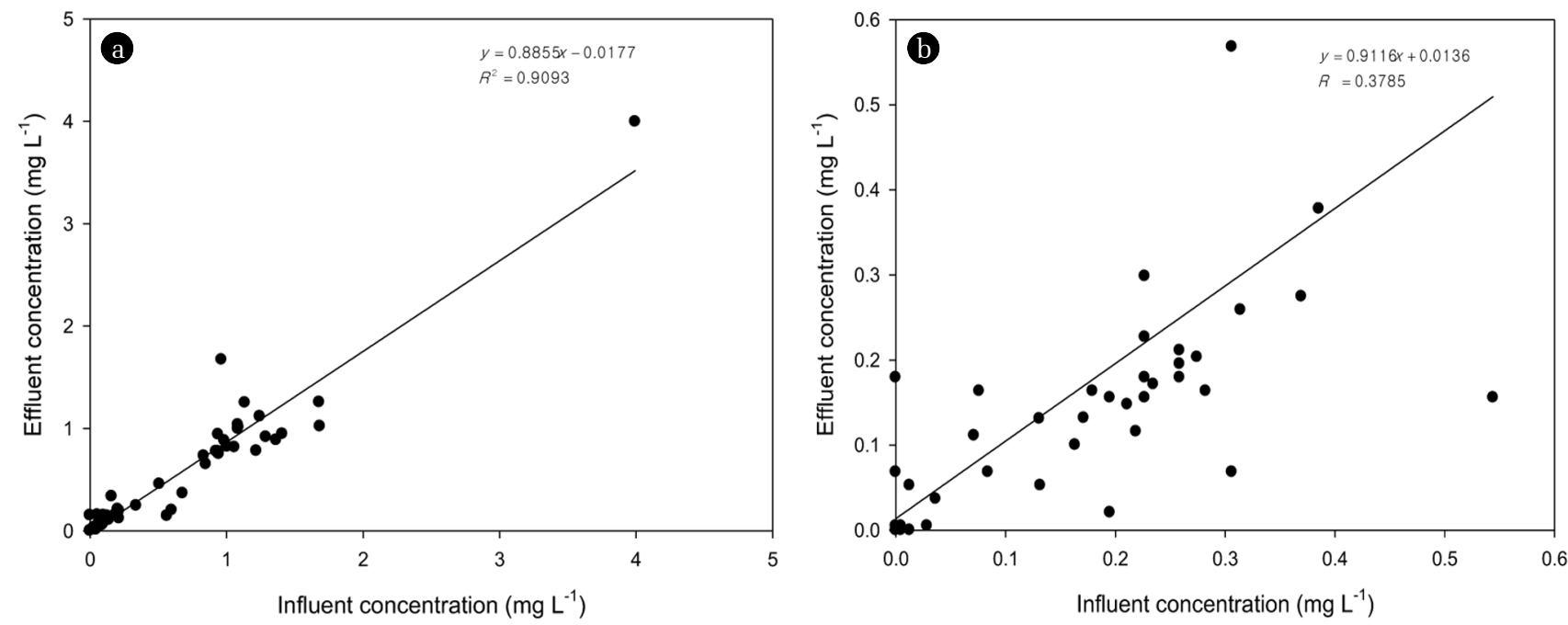

Fig. 6. Concentration of effluent phosphorus according to influent phosphorus concentration. 
NOM is difficult to remove through only biological treatment methods, so physical and chemical treatment methods are often used together [22]. When mixed wastewater, which contained municipal wastewater, was influent, the removal efficiency was not enhanced. During this period, the average concentrations of influent TCOD and SCOD were much lower, around 6.973 and $4.332 \mathrm{mg} \mathrm{L}^{-1}$. Contrary to the treatment of low concentrations of ammonia nitrogen, the treatment efficiency of low concentrations of organic matter was not high.

The effluent-phosphorus concentration is shown in Fig. 6 and was similar to COD removal. In fact, the removal of phosphorus was rarely achieved in this study. Phosphorus removal in attached-growth methods and biofilm technology such as BAFs is difficult because of the treatment mechanism of phosphorus. Many studies suggested the use of coagulants for phosphorus removal [23-25]. This study also considered that the additional use of coagulants is necessary to remove phosphorus in ZBAFs.

\section{Conclusions}

The ZBAF maintained its ammonia-nitrogen-treatment efficiency under lower concentrations. The effect of the water temperature was very small, so this filter can be applied even during winter. ZBAFs can be applied wherever low concentrations of ammonia nitrogen are present and can be complemented by ammonia-nitrogen treatment in wastewater-treatment plants or aquaculture wastewater treatment.

1) When a low concentration ammonia nitrogen synthetic wastewater was influent, only zeolite media occurred nitrification. The average ammonia nitrogen removal efficiency of ZBAF was $63.38 \%$.

2) Pond water which contains low concentration ammonia nitrogen was shown similar treatment trend. Especially, ZBAF was maintained a high treatment efficiency of $79 \%$ even at $4.7^{\circ} \mathrm{C}$.

3) On the other hand, the COD and phosphorus-removal efficiency were very low. At low concentrations, the ZBAF showed remarkable performance with ammonia treatment but little performance with COD and phosphorus removal.

\section{Acknowledgements}

This work was financially supported by the Research Year of Chungbuk National University in 2018.

\section{References}

1. Wang Y, Kmiya Y, Okuhara T. Removal of low-concentration ammonia in water by ion-exchange using Na-mordenite. Water Res. 2007;41:269-276.

2. Li M, Zhu X, Zhu F, Ren G, Cao G, Song L. Application of modified zeolite for ammonium removal from drinking water. Desalination 2011;273:295-300.

3. Wang S, Peng Y. Natural zeolites as effective adsorbents in water and wastewater treatment. Chem. Eng. J. 2010;156:11-24.

4. Moussavi G, Talebi S, Farrokhi M, Sabouti RM. The investigation of mechanism, kinetic and isotherm of ammonia and humic acid co-adsorption onto natural zeolite. Chem. Eng. J. 2011;171:1159-1169.

5. Sarioglu M. Removal of ammonium from municipal wastewater using natural Turkish (Dogantepe) zeolite. Sep. Purif. Technol. 2005;41:1-11.

6. Karadag D, Koc Y, Turan M, Amagan B. Removal of ammonium ion from aqueous solution using natural Turkish clinoptilolite. J. Hazard. Mater. 2006;136:604-609.

7. Demir A, Gunay A, Debik E. Amonium removal from aqueous solution by ion-exchange using packed bed natural zeolite. Water SA. 2002;28:329-336.

8. Lahv O, Green M. Ammonium removal using ion exchange and biological regeneration. Water Res. 1998;32:2019-2028.

9. Jung JY, Chung YC, Shin HS, Son DH. Enhanced ammonia nitrogen removal using consistent biological regeneration and ammonium exchange of zeolite in modified SBR process. Water Res. 2004;38:347-354.

10. Zhao X, Wang Y, Ye Z, Borthwick AG, Ni J. Oil field wastewater treatment in biological aerated filter by immobilized microorganisms. Process Biochem. 2006;41:1475-1483.

11. Ryu HD, Kim JS, Kang MK, Lee SI. Enhanced nitrification at short hydraulic retention time using a 3-stage biological aerated filter system incorporating an organic polishing reactor. Sep. Purif. Technol. 2014;136:190-206.

12. Qiu, L, Zhang, S, Wang, G. Performances and nitrification properties of biological aerated filters with zeolite, ceramic particle and carbonate media. Bioresour. Technol. 2010;101:7245-7251.

13. Ji G, Tong J, Tan Y. Wastewater treatment efficiency of a multi-media biological aerated filter (MBAF) containing clinoptilolite and bioceramsite in a brick-wall embedded design. Bioresour. Technol. 2011;102:550-557.

14. Chang WS, Hong SW, Park JK. Effect of zeolite media for the treatment of textile wastewater in a biological aerated filter. Process Biochem. 2002;37:693-698.

15. He SB, Xue G, Kong HN. The performance of BAF using natural zeolite as filter media under conditions of low temperature and ammonium shock load. J. Hazard. Mater. 2007;143:291-295.

16. Chang WS, Tran HT, Park DH, Zhang RH, Ahn DH. Ammonium nitrogen removal characteristics of zeolite media in a Biological Aerated Filter (BAF) for the treatment of textile wastewater. J. Ind. Eng. Chem. 2009;15:524-528.

17. Feng T, Qi J, Chi L, Wang D, Wang Z, Li K, Li X. Production of sorption functional media (SFM) from clinoptilolite tailings and its performance investigation in a biological aerated filter (BAF) reactor. J. Harzard. Mater. 2013;246:61-69.

18. Li Q, Sun S, Guo T, Yang C, Song C, Geng W, Zhang W, Feng J, Wang, S. Short-cut nitrification in biological aerated filters with modified zeolite and nitrifying sludge. Bioresour technol. 2013;136:148-154.

19. Yang Y, Chen Z, Wang X, Zheng L, Hu X. Partial nitrification performance and mechanism of zeolite biological aerated filter for ammonium wastewater treatment. Bioresour. Technol. 2017;241:473-481.

20. Young B, Delatolla R, Kennedy K, Laflamme E, Stintzi A. Low temperature MBBR nitrification: Microbiome analysis. Water Res. 2017;111:224-233. 
21. Payraudeau M, Pearce AR, Goldsmith R, Bigot B, Wicquart F. Experience with an up-flow biological aerated filter (BAF) for tertiary treatment: from pilot trials to full scale implementation. Water Sci. Technol. 2001;44:63-68.

22. Huang G, Meng F, Zheng X, Wang Y, Wang Z, Liu H, Jekel M. Biodegradation behavior of natural organic matter (NOM) in a biological aerated filter (BAF) as a pretreatment for ultrafiltration (UF) of river water. Appl. Microbiol. Biotechnol. 2011;90:1795-1803.

23. Clark T, Stephenson T, Pearce PA. Phosphorus removal by chemical precipitation in a biological aerated filter. Water Res. 1997;31:2557-2563.

24. Wang H, Dong W, Li T, Liu T. Enhanced synergistic denitrification and chemical precipitation in a modified BAF process by using $\mathrm{Fe}^{2+}$. Bioresour. Technol. 2014;151:258-264.

25. Wang H, Dong W, Li T, Liu T. Amodified BAF system configuring synergistic denitrification and chemical phosphorus precipitation: examination on pollutants removal and clogging development. Bioresour. Technol. 2015;189:44-52. 